\title{
Penerapan Green Accounting dan Corporate Social Responsibility Disclosure Terhadap Nilai Perusahaan Melalui Profitabilitas
}

\author{
Catur Muhammad Erlangga ${ }^{*}$, Achmad Fauzi ${ }^{2}$, Ati Sumiati ${ }^{3}$ \\ 1, 2, 3 Universitas Negeri Jakarta, Indonesia \\ ${ }^{1}$ caturerlangga@gmail.com; ${ }^{2}$ fau_smart@unj.ac.id; ${ }^{3}$ ati-sumiati@unj.ac.id \\ ${ }^{*}$ Penulis korespondensi
}

\begin{abstract}
This study aims to provide an overview of Green Accounting, disclosure of corporate social responsibility, company profitability and company value in manufacturing companies listed on the Indonesia Stock Exchange in 2019. The research method used is quantitative method with descriptive and verification methods. The sample of this research is 200 manufacturing companies listed on the Indonesia Stock Exchange in 2019. The data analysis method used in this study is the expansion path analysis of simple and multiple regression analysis, single test, multiple correlation coefficient (R) analysis, and coefficient of determination. While the hypothesis testing used is the statistical method of partial test ( $t$ test), simultaneous test ( $\mathrm{f}$ test) and Sobel significant test using Eviews version 10 Enterprise. The results showed that there was a positive and significant effect on the implementation of Green Accounting and Corporate Social Responsibility Disclosure on the profitability and firm value. Profitability also significantly affected firm value, but the mediating effect of the profitability variable did not occur.
\end{abstract}

Keywords: Implementation of Green Accounting, Corporate Social Responsibility Disclosure, Profitability, Company Value, Manufacturing Company

\begin{abstract}
Abstrak
Penelitian ini bertujuan untuk memberikan gambaran tentang Green Accounting, pengungkapan tanggung jawab sosial perusahaan, profitabilitas perusahaan dan nilai perusahaan pada perusahaan manufaktur yang terdaftar di Bursa Efek Indonesia tahun 2019. Metode penelitian yang digunakan adalah metode kuantitatif dengan metode deskriptif dan verifikatif. Sampel penelitian ini adalah 200 perusahaan manufaktur yang terdaftar di Bursa Efek Indonesia tahun 2019. Metode analisis data yang digunakan dalam penelitian ini yaitu analisis jalur perluasan dari analisis regresi sederhana dan berganda, uji sobel, analisis koefisien korelasi ganda (R), dan koefisien determinasi. Sedangkan pengujian hipotesis yang digunakan adalah metode statistik uji parsial (uji t), uji simultan (uji f) dan uji siginifikan sobel menggunakan Eviews versi 10 Enterprise. Hasil penelitian menunjukkan bahwa terdapat pengaruh positif dan signifikan atas penerapan Green Accounting dan Corporate Social Responsibility Disclosure terhadap profitabilitas dan nilai perusahaan, profitabilitas juga mempengaruhi nilai perusahaan secara signifikan, namun pengaruh mediasi dari variabel profitabilitas tidak terjadi.
\end{abstract}

Kata Kunci: Penerapan Green Accounting, Corporate Social Responsibility Disclosure, Profitabilitas, Nilai Perusahaan, Perusahaan Manufaktur 


\section{PENDAHULUAN}

Pada era industrialisasi dan globalisasi yang semakin kompetitif saat ini, segala macam kebutuhan masyrakat dapat dipenuhi melalui proses produksi dan distribusi yang secara masif dan cepat. Muncul berbagai perusahaan yang siap menyediakan berbagai kebutuhan masyarakat, hal ini mendorong terjadinya persaingan usaha yang terus-menerus. Persaingan yang ketat baik di pasar domestik maupun internasional menuntut perusahaan untuk terus mempertahankan posisinya dipasar dengan terus melakukan produksi dan siap memasok permintaan pasar. Mempertahankan dan juga meningkatkan profitabilitasnya adalah tujuan utama perusahaan dengan memfokuskan pada kegiatan operasional dan finansial perusahaan.

Perusahaan yang baik harus mampu mengelola potensi keuangan dan non keuangannya agar dapat memaksimalkan nilai perusahaan untuk kelangsungan hidupnya dalam jangka panjang. Memaksimalkan nilai perusahaan sangat penting bagi perusahaan, karena juga berarti memaksimalkan kemakmuran pemegang saham yang merupakan tujuan utama perusahaan (Soliha \& Taswan, 2002). Nilai perusahaan yang tinggi akan berdampak pada kepercayaan investor pada kinerja perusahaan saat ini dan masa yang akan datang. Pihak investor menilai kinerja perusahaan menurut kemampuan perusahaan pada pengelolaan sumber daya yang dimiliki untuk meningkatkan profitabilitas.

Memperoleh laba secara maksimal melalui pemanfaatan sumber daya yang ada merupakan tujuan jangka pendek sebuah perusahaan, sedangkan tujuan jangka panjang perusahaan adalah memaksimalkan nilai perusahaan (Dewi \& Narayana, 2020)profitability, and corporate social responsibility on firm value. The sample of this study is mining companies listed on the Indonesia Stock Exchange (IDX. Jika suatu perusahaan memiliki tingkat profitabilitas yang baik maka berpeluang untuk memperoleh investasi modal. Untuk mencapai tujuan perusahaan dalam memperoleh laba yang maksimum adalah dengan mendapatkan perhatian dari konsumen melalui pemberian perhatian atas kepentingan lingkungan dan sosial. Melalui Green Accounting dan Corporate Social Responsibility Disclosure perusahaan berusaha menurangi atau menghindari kerugian atas kerusakan lingkungan dimasa yang akan datang serta menciptakan keunggulan kompetititf melalui hasil produksi yang ramah lingkungan (Kusumaningtias, 2013). Keuntungan sosial yang signifikan akan memperbaiki citra perusahaan (Mowen et al., 2016, p. 403). Citra perusahaan yang baik akan merangsang minat beli masyarakat sehingga meningkatkan jumlah penjualan yang akan mempengaruhi profitabilitas perusahaan. Citra yang baik juga dapat meningkatkan daya tarik investasi investor. Peningkatan indeks bagi investor ditandai dengan naiknya harga saham perusahaan. Dengan cara ini, mengirimkan sinyal terpisah bahwa perusahaan perlu memberikan informasi kepada pihak eksternal untuk menjaga citra perusahaan (Omran \& Ramdhony, 2015).

Menurut Riyadh et al. (2020), teori legitimasi menekankan anggapan bahwa perusahaan harus mempertahankan fungsi sosialnya dengan memenuhi kebutuhan sosial dan memberikan citra yang lebih tinggi kepada masyarakat. Teori sinyal juga mengungkapkan bagaimana sinyal keberhasilan dan kegagalan diungkapkan kepada pemilik perusahaan. Pentingnya 
informasi yang dikeluarkan perusahaan terhadap keputusan investasi pihak eksternal, dan mendorong perusahaan untuk memberikan informasi yang lebih luas kepada pihak eksternal (Brigham \& Houston, 2007). Menurut Mardikanto (2014), teori stakeholder adalah konsep manajemen strategis bertujuan untuk membantu perusahaan mengembangkan keunggulan kompetitif dan memperkuat hubungannya dengan pihak eksternal. Berdasarkan hal tersebut maka peneliti berasumsi bahwa melalui pengungkapan Green Accounting dan Corporate Social Responsibility Disclosure memberikan dampak positif baik itu bagi perusahaan terhadap pihak eksternal.

Menurut Ikhsan (2008) dan Risal et al. (2020), akuntansi hijau (Green Accounting) ialah proses dimasukkannya biaya lingkungan (environmental costs) dalam proses penyusunan laporan akuntansi perusahaan, organisasi atau lembaga. Biaya lingkungan adalah biaya yang timbul dari sisi keuangan maupun non-keuangan yang harus ditanggung sebagai akibat dari kegiatan perusahaan yang mempengaruhi kualitas lingkungan.

Menurut Nurkhin (2009), pengungkapan tanggung jawab sosial adalah informasi terkait kegiatan tanggung jawab sosial perusahaan yang disediakan oleh agen CSRDI (Indeks Pengungkapan Tanggung Jawab Sosial Perusahaan) dan indikator GRI (Global Reporting Initiative).

Menurut Munawir (2014) profitabilitas menunjukkan kemampuan perusahaan dalam menghasilkan laba dalam waktu tertentu. Kasmir (2018) juga mengemukakan definisi profitabilitas yang lain, yaitu rasio profitabilitas adalah rasio kemampuan mengevaluasi efektivitas manajemen suatu perusahaan. Semakin tinggi laba perusahaan maka disimpulan perusahaan tersebut dalam kinerja baik, begitu pula sebaliknya (Rahayu, 2020)alat ukur dalam mengukur rasio profitabilitas adalah dengan menggunakan return on equity (ROE. Hal ini terlihat dari laba yang dihasilkan atas penjualan dan hasil investasi.

Definisi lain nilai perusahaan menurut Harmono (2014), adalah kinerja perusahaan yang diperlihatkan melalui pergerakan harga saham dari perilaku permintaan dan penawaran di pasar modal atas penilaian masyarakat dari kinerja perusahaan.

Menurut hasil penelitian Ezeagba et al. (2017) pada perusahaan makanan dan minuman, environmental accounting berpengaruh signifikan terhadap Return on Equity, sehingga dapat memberikan nilai bagi perusahaan terhadap pengambilan keputusan. Penelitian lain (Andries \& Stephan, 2019) mengemukakan bahwa inovasi lingkungan dikembangkan sebagai bentuk respons terhadap permintaan pelanggan, regulasi, ketersediaan subsidi, atau kode etik dalam industri, bergantung pada ukuran perusahaan. Penemuan ini memperluas pekerjaan yang ada dengan menyoroti kondisi batas utama hubungan antara inovasi lingkungan dan kinerja keuangan. Penelitian yang dilakukan oleh Wangi \& Lestari (2020) memperoleh hasil bahwa pengaruh penerapan Green Accounting yang diukur dengan kinerja lingkungan berpengaruh terhadap tingkat profitabilitas perusahaan pada perusahaan manufaktur yang terdaftar di Bursa Efek Indonesia tahun 2016-2018. Berdasarkan hasil penelitian terhadulu, diambil hipotesis seperti berikut:

$\mathrm{H}_{1}$ : Penerapan Green Accounting berpengaruh signifikan terhadap profitabilitas. 
Pelaksanaan CSR mendatangkan citra positif bagi perusahaan (Nor, 2011) baik dipasar komoditas maupun pasar bursa yang akan menimbulkan profit yang lebih tinggi bagi perusahaan. Angelia \& Suryaningsih (2015) menyatakan bahwa perusahaan yang mengembangkan dan mengungkapkan tanggung jawab sosial perusahaan dalam laporan keuangannya akan mendapat respon yang lebih baik dari masyarakat dengan meningkatnya kepercayaan masyarakat maka tingkat penjualan perusahaan akan meningkat. Rosdwianti \& Dzulkirom AR (2016) dalam penelitiannya menjelaskan bahwa CSR berpengaruh signifikan terhadap ROA. Sedangkan Wulandari (2020) menyatakan hubungan CSRD terhadap profitabilitas memberikan hasil bahwa variabel CSR Disclosure memiliki pengaruh positif dan signifikan untuk memproyeksikan hasil profitabilitas perusahaan dengan rasio ROA, ROE, dan NPM. Berdasarkan hal tersebut, maka dirumuskan hipotesis seperti berikut:

H2: Corporate social responsibility (CSR) disclosure berpengaruh signifikan terhadap profitabilitas

Hal tersebut sejalan dengan penelitian terkait profitabilitas (ROA) yang secara signifikan berpengaruh positif terhadap nilai perusahaan yang dilakukan (Ayem \& Nugroho, 2016; Ayu \& Suarjaya, 2017). Hasil penelitian tersebut menunjukkan bahwa dalam kinerja keuangan perusahaan berpengaruh positif terhadap nilai pasar perusahaan (Endiana et al., 2020). Hal tersebut didukung oleh penelitian yang dikemukakan oleh Sari (2020) yang membuktikan bahwa profitabilitas berpengaruh positif terhadap nilai perusahaan bahwa perolehan laba yang tinggi meningkatkan pembayaran deviden sehingga berpengaruh pada kenaikan harga saham. Berdasarkan hal tersebut, maka dirumuskan hipotesis seperti berikut:

H3: Profitabilitas berpengaruh signifikan terhadap nilai perusahaan

Penelitian Pratiwi \& Rahayu (2018) dan Zulhaimi (2015) mengungkapkan bahwa terdapat kenaikan pertumbuhan harga saham setelah menerapkan green accounting. Hasil penelitian tersebut sejalan dengan yang dikemukakan oleh Abdurrahman (2019) yang membuktikan akuntansi keuangan lingkungan, ekologi, akuntansi, akuntansi biaya lingkungan, pengelolaan lingkungan akuntansi dan akuntansi sumber daya alam yang memiliki keterkaitan yang kuat dengan nilai perusahaan. Hasil penelitian Dewi \& Narayana (2020) menunjukkan bahwa penerapan green accounting berpengaruh positif signifikan terhadap nilai perusahaan. Berdasarkan hal tersebut, maka dirumuskan hipotesis seperti berikut:

H4: Penerapan Green Accounting berpengaruh signifikan terhadap nilai perusahaan

Menurut Hamdani (2016), tanggungjawab sosial perusahaan merupakan program yang memberikan nilai tambah bagi semua stakeholder dan rasa percaya terhadap perusahaan. Menurut Chen \& Lee (2017), semakin luas pengungkapan tanggung jawab sosial perusahaan, 
maka semakin besar nilai perusahaan. Hal tersebut dibuktikan berdasarkan penelitian yang telah dilakukan oleh Dewi \& Narayana (2020) yaitu variabel Corporate Social Responsibility berpengaruh positif signifikan terhadap nilai perusahaan. Berdasarkan hal tersebut, maka dirumuskan hipotesis seperti berikut:

H5: Corporate social responsibility (CSR) disclosure berpengaruh signifikan terhadap nilai perusahaan

Mowen et al. (2016) berpendapat bahwa melalui keunggulan kompetitif yang ditawarkan oleh perusahaan dengan adanya kepedulian terhadap lingkungan dan sosial akan membawa citra baik bagi perusahaan. Menurut Yulianty \& Nugrahanti (2020) sustainability reporting (laporan berkelanjutan) berpengaruh signifikan terhadap nilai perusahaan melalui kinerja keuagan yang diproksikan oleh likuiditas, profitabilitas, dan DuPont System. Selain itu, Khairiyani et al. (2019) menyatakan bahwa kinerja lingkungan yang tercermin dalam skala PROPER berdampak pada kinerja keuangan. PBV dan Tobin's Q mencerminkan dampak kinerja lingkungan terhadap nilai perusahaan. Berdasarkan hal tersebut, maka dirumuskan hipotesis seperti berikut:

H6: Profitabilitas mampu memediasi hubungan antara penerapan Green Accounting terhadap nilai perusahaan

Hasil penelitian Dianawati \& Fuadati (2016) menyatakan bahwa nilai perusahaan yang menguntungkan berada di tengah yang menunjukkan bahwa tanggung jawab sosial perusahaan (CSR) berpengaruh signifikan dan positif terhadap nilai perusahaan, semakin baik tanggung jawab sosial perusahaan (CSR) akan meningkatkan nilai perusahaan. Nor (2011) mengatakan bahwa citra baik yang timbul dalam pasar komoditi akibat dari kemampuan perusahaan dalam mengungkapkan CSR akan mendatangkan margin profit yang lebih tinggi, maka perusahaan mampu memberikan nilai perusahaan yang lebih tinggi dalam posisi di pasar saham dan mendorong investor dalam menanamkan modalnya. Selain itu, Masitoh \& Suprijanto (2018) menunjukkan bahwa profitabilitas memediasi CSR terhadap nilai perusahaan. Menurut Suhartini \& Megasyara (2019) profitabilitas mungkin merupakan variabel perantara. Hal ini menunjukkan bahwa ketika perusahaan melakukan pengungkapan tanggung jawab sosial perusahaan, profitabilitas sebagai variabel antara dapat meningkatkan nilai perusahaan. Berdasarkan beberapa hasil dari penelitian tersebut, maka dirumuskan hipotesis sebagai berikut:

$\mathrm{H}_{7}$ : Profitabilitas mampu memediasi hubungan antara corporate social responsibility disclosure terhadap nilai perusahaan

\section{METODE}

Metode yang digunakan dalam penelitian ini adalah metode penelitian kuantitatif dengan pendekatan asosiatif. Hal ini untuk mengetahui gambaran objek penelitian dan pengaruh antara variabel bebas dan variabel terikat yang dimediasi oleh adanya variabel 
antara. Metode yang digunakan dalam penelitian ini adalah metode deskriptif dan verifikatif. Penelitian ini dilakukan dalam satu waktu yaitu tahun 2019 dengan subjek penelitian yang berbeda sub-sektor disebut juga sebagai penelitian cross-section. Populasi penelitian yaitu perusahaan manufaktur yang terdaftar di Bursa Efek Indonesia (BEI) pada tahun 2019. Perusahaan sektor manufaktur meliputi beberapa sektor antara lain industri dasar dan kimia dengan sub-sektornya (semen, keramik porselen kaca, Logam, kimia, plastik, pakan ternak, kayu, dan pulp-kertas), sektor consumer goods dengan sub-sektornya (makananminuman, rokok, farmasi, kosmetika houseware dan household), dan terakhir sektor industri dengan sub-sektornya (mesin alat berat, komponen otomotif, tekstil-garment, alas kaki, kabel, elektronika dan lainnya). Untuk menentukan populasi terjangkau, maka penyeleksian terlebih dahulu dengan menggunakan kriterium.

Tabel 1 Hasil Populasi Terjangkau

\begin{tabular}{lc}
\hline \multicolumn{1}{c}{ Keterangan } & Jumlah Perusahaan \\
\hline Perusahaan Manufaktur yang listing di BEI pada tahun 2019. & 200 \\
Kriteria: & \\
Perusahaan Manufaktur yang tidak melampirkan laporan keuangan tahunan & $(0)$ \\
pada tahun 2019 & \\
Perusahaan Manufaktur yang terdaftar di BEI dan tidak mengikuti program & $(73)$ \\
PROPER pada tahun 2019 & $(27)$ \\
Perusahaan Manufaktur yang mengalami kerugian pada tahun 2019 & 100 \\
Jumlah populasi terjangkau & \\
\hline
\end{tabular}

Sumber: olah data peneliti, 2021

Dalam penelitian ini, peneliti menggunakan probability sampling dengan jenis simple random sampling. Penentuan jumlah sampel dalam penelitian ini dengan menggunakan Isaac dan Michael dengan memberikan hasil perhitungan yang dipakai untuk menentukan jumlah sampel berdasarkan tingkat kesalahan 5\%. Rumus Isaac dan Michael adalah sebagai berikut:

$$
\begin{gathered}
S=\frac{\lambda^{2} \cdot N \cdot P \cdot Q}{d^{2}(N-1)+\lambda^{2} P(1-P)} \\
S=\frac{3.841 \times 100 \times 0.5 \times 0.5}{\left(0.05^{2} \times(140-1)\right)+(3.841 \times 0.5 \times 0.5)}=70
\end{gathered}
$$

Maka diperlukan 70 perusahaan manufaktur yang dijadikan sampel dalam penelitian ini.

Untuk menguji pengaruh variabel intervening maka digunakan analisis jalur. Metode analisis data yang digunakan dalam penelitian ini yaitu analisis jalur perluasan dari analisis regresi sederhana dan berganda, uji sobel, analisis koefisien korelasi ganda (R), dan koefisien determinasi. Sedangkan pengujian hipotesis yang digunakan adalah uji parsial (uji t), uji simultan (uji f) dan uji siginifikan sobel menggunakan E-Views versi 10 Enterprise. 
Berikut ini adalah persamaan struktural yang menunjukkan hubungan antar variabel pada diagram jalur yang dibuat:

Gambar 1. Diagram Jalur $X_{1}, X_{2}$ dan Z Terhadap $Y$

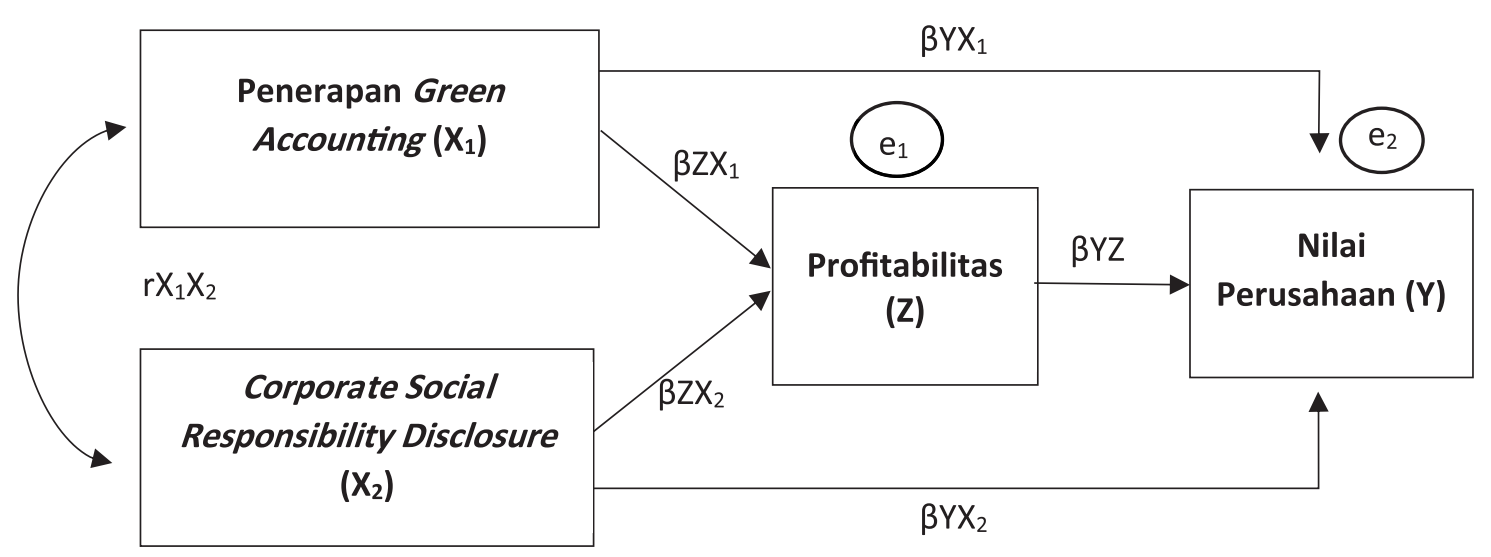

Berdasarkan diagram jalur yang telah dibuat diatas dapat dilihat bagaimana jalur pengaruh langsung dan tidak langsung. Pengaruh langsung adalah pengaruh dari variabel independen ke variabel dependen tanpa melalui variabel lain yang disebut variabel intervening, sedangkat pengaruh tidak langsung melewati variabel intervening terlebih dahulu. Untuk lebih jelasnya dapat dilihat sebagai berikut:

1) Pengaruh Langsung (Direct Effect)

$$
\begin{aligned}
& \mathrm{X}_{1}, \mathrm{X}_{2} \longrightarrow \mathrm{Y:} \beta \mathrm{YX}_{1}, \beta \mathrm{YX}_{2} \\
& \mathrm{Y} \longrightarrow \mathrm{Z}: \beta \mathrm{YZ} \\
& \mathrm{Z} \longrightarrow \mathrm{e}_{1}
\end{aligned}
$$

2) Pengaruh Tidak Langsung (Indirect Effect)

$$
\mathrm{X}_{1}, \mathrm{X}_{2} \longrightarrow \mathrm{Y} \longrightarrow \mathrm{Z}: \beta \mathrm{ZX}_{1}, \beta \mathrm{ZX}_{2} \text {, dan } \beta \mathrm{YZ}
$$

Persamaan tersebut memperlihatkan bahwa pengaruh langsung diperoleh dari nilai koefisien jalur dependen terhadap independennya, sedangkan hasil tidak langsung diperoleh dengan mengalikan koefisien jalur nilai variabel independen yang melewati variabel intervening dengan koefisien jalur nilai variabel interveningnya terhadap variabel dependen.

\section{HASIL DAN PEMBAHASAN}

Analisis statistik deskriptif dalam penelitian ini bertujuan untuk memberikan gambaran dari variabel penelitian dalam bentuk perhitungan statistif seperti mean, median, standar deviasi dan tabulasi data frekuensi yang akan ditampilkan sebagai berikut: 
Tabel 2 Analisis Deskriptif Common Sampel

\begin{tabular}{ccccc}
\hline Uraian & $\mathbf{X 1}$ & $\mathbf{X} 2$ & $\mathbf{Z}$ & $\mathbf{Y}$ \\
\hline Mean & 0.435366 & 0.5363 & 2.745 & 1.548 \\
Median & 0.426829 & 0.540984 & 2.58 & 1.09 \\
Maximum & 0.841463 & 0.885246 & 6.56 & 5.09 \\
Minimum & 0.158537 & 0.245902 & 0.06 & 0.24 \\
Std. Dev. & 0.159551 & 0.143734 & 1.732592 & 1.1509 \\
Skewness & 0.791757 & 0.413965 & 0.499934 & 1.438542 \\
Kurtosis & 3.174307 & 2.880745 & 2.615674 & 4.236646 \\
Jarque-Bera & 7.402215 & 2.040765 & 3.346711 & 28.60347 \\
Probability & 0.024696 & 0.360457 & 0.187616 & 0.000001 \\
Sum & 30.47561 & 37.54098 & 192.15 & 108.36 \\
Sum Sq. Dev. & 1.756499 & 1.4255 & 207.1294 & 91.39532 \\
Observations & 70 & 70 & 70 & 70 \\
\hline
\end{tabular}

Sumber: olah data peneliti, 2021

Data Penerapan Green Accounting (X1) melalui skor GRI dengan total item 61 memperoleh hasil nilai minimum sebesar 0.158 dan nilai maksimum sebesar 0.841 pada tahun 2019 diketahui nilai mean sebesar 0.435 dengan persentase akhir pengungkapan sebesar 43.5\% dari 100\% (82 Item) artinya perusahaan manufaktur di Indonesia masih tergolong rendah dalam Penerapan Green Accounting dengan nilai standar deviasi sebesar 0.159 yang artinya nilai mean lebih besar dari nilai standar deviasi sehingga kesimpulannya variasi data tergolong rendah dan terhindar dari penyimpangan data.

Data Corporate Social Responsibility Disclosure (X2) melalui skor GRI-G4 dengan total 61 item memperoleh hasil nilai minimum sebesar 0.245 dan nilai maksimum sebesar 0.885 pada tahun 2019 diketahui nilai mean sebesar 0.536 dengan persentase akhir sebesar 53.6\% dari 100\% (61 Item) artinya perusahaan manufaktur di Indonesia masih tergolong rendah dalam Corporate Social Responsibility Disclosure dengan nilai standar deviasi sebesar 0.143 yang artinya nilai mean lebih besar dari nilai standar deviasi sehingga kesimpulannya variasi data tergolong rendah dan terhindar dari penyimpangan data.

Data Profitabilitas (Z) melalui nilai Return on Equity (ROE) dengan total memperoleh hasil nilai minimum sebesar 0.06 dan nilai maksimum sebesar 6.56 pada tahun 2019 diketahui nilai mean sebesar 2.745 dengan nilai standar deviasi sebesar 1.732 yang artinya nilai mean lebih besar dari nilai standar deviasi sehingga kesimpulannya variasi data tergolong rendah dan terhindar dari penyimpangan data.

Data Nilai Perusahaan (Y) melalui perhitungan Tobins'Q dengan hasil nilai minimum sebesar 0.24 dan nilai maksimum sebesar 5.09 pada tahun 2019 diketahui nilai mean 
sebesar 1.54 dengan nilai standar deviasi sebesar 1.15 yang artinya nilai mean lebih besar dari nilai standar deviasi sehingga kesimpulannya variasi data tergolong rendah dan terhindar dari penyimpangan data.

Analisis regresi digunakan untuk mengukur seberapa kuat hubungan antara dua variabel atau lebih, serta menunjukkan arah hubungan dari variabel bebas terhadap variabel terikat, sehingga dapat digunakan untuk menjawab hipotesis yang telah dibuat sebelumnya. Hasil analisis regresi dapat dilihat pada tabel-tabel berikut:

Tabel 3 Regresi Linear Berganda X Terhadap Z

\begin{tabular}{cclcc}
\hline \multicolumn{1}{c}{ Variable } & Coefficient & Std. Error & t-Statistic & Prob \\
\hline C & -2.128221 & 0.525254 & -4.051793 & 0.0001 \\
X1 & 5.616644 & 0.968717 & 5.798024 & 0.00 \\
\hline R-squared & 5.527181 & 1.075319 & 4.210082 & 0.0001 \\
Adjusted R-squared & 0.609677 & Mean dependent var & & 2.745 \\
S.E. of regression & 0.598025 & S.D. dependent var & 1.732592 \\
Sum squared resid & 1.098489 & Akaike info criterion & 3.06766 \\
Log likelihood & 80.84744 & Schwarz criterion & & 3.164024 \\
F-statistic & -104.3681 & Hannan-Quinn criter. & & 3.105937 \\
Prob(F-statistic) & 52.32626 & & & 1.080976 \\
\hline
\end{tabular}

Sumber: olah data peneliti, 2021

Berdasarkan tabel 3, hasil uji menunjukkan bahwa variabel penerapan green accounting mempunyai hasil probabilitas $0.000<0.05$ yang artinya memiliki pengaruh dan signifikan terhadap profitabilitas yang diproyeksikan Return on Equity (ROE) dan memiliki arah hubungan positif dengan nilai koefisien regresi sebesar 5.616644 artinya profitabilitas akan meningkat sebesar 5.61 apabila perusahaan mampu mengungkapkan salah satu aspek atau kriteria penerapan green accounting dalam perusahaan. Hal ini sejalan dengan beberapa penelitian sebelumnya (Endiana et al., 2020; Risal et al., 2020; Wangi \& Lestari, 2020) yang menyatakan bahwa dengan pengalokasian biaya lingkungan dan praktek kerja lingkungan ke dalam operasional perusahaan akan menciptakan keunggulan kompetitif dalam pasar, hal ini akan mendorong persepsi positif dan loyalitas pelanggan terhadap produk atau jasa yang ditawarkan perusahaan. Penerapan green accounting dapat diterapkan melalui CSMS (Corporate Sustainability Management System) yang telah disusun oleh Ikatan Akuntansi Indonesia agar perusahaan dapat menyelaraskan kebijakan dalam menetapkan alokasi biaya untuk aktivitas lingkungan, investasi dan pembiayaan agar sesuai dengan kebutuhan konsumen dan kapabilitas perusahaan.

Variabel Corporate Social Responsibility Disclosure mempunyai hasil probabilitas $0.0001<$ 0.05 yang artinya memiliki pengaruh dan signifikan terhadap profitabilitas yang diproyeksikan 
Return on Equity (ROE) dan memiliki arah hubungan positif dengan nilai koefisien regresi sebesar 4.527181 artinya profitabilitas akan meningkat sebesar 4.52 apabila perusahaan mampu mengungkapkan salah satu aspek atau kriteria Corporate Social Responsibility Disclosure dalam perusahaan. Hal ini sejalan dengan beberapa penelitian sebelumnya (Ali et al., 2019; Cahyanti et al., 2018; Wulandari, 2020) dengan adanya keberadaan pengungkapan CSR dalam perusahaan akan membuat rasa percaya dan aman atas kualitas keamanan produk atau jasa yang ditawarkan oleh perusahaan, tentu hal ini akan menjaga citra dan persepsi konsumen atas perusahaan, berkaitan dengan stakeholder antara lain investor dan masyarakat perlu mengetahui informasi non-keuangan perusahaan antara lain hak asasi karyawan dan masyarakat, kontribusi perusahaan terhadap masyarakat dan lingkungan, serta SOP operasional perusahaan, hal ini diperuntukkan untuk memprediksi reputasi dan keberlangsungan perusahaan diwaktu yang akan datang.

Berdasarkan hasil uji pada tabel 4, menunjukan variabel profitabilitas (ROE) mempunyai hasil probabilitas $0.011<0.05$ yang artinya memiliki pengaruh dan signifikan terhadap nilai perusahaan yang diproyeksikan Tobins' $Q$ dan memiliki arah hubungan positif dengan nilai koefisien regresi sebesar 0.253788 artinya nilai perusahaan akan meningkat sebesar 0.25 apabila perusahaan mampu menaikkan profitabilitas sebesar 1\% dalam laba bersih. Hal ini sejalan dengan penelitian Ayu \& Suarjaya (2017), Sari (2020), dan Zuhroh (2019) yang menyatakan bahwa sesuai dengan teori sinyal apabila perusahaan mampu mencapai tingkat proft yang baik maka akan memberikan sinyal atau sentiment positif kepada investor terhadap keberalangsungan perusahaan dan kemampuan perusahaan dalam membayar tingkat dividen yang tinggi, hal ini tentu akan memberikan respons terhadap ketertarikan dalam berinvestasi dan mmampu meningkatkan harga saham dalam pasar bursa.

Tabel 4 Regresi Linear Sederhana Y Terhadap Z

\begin{tabular}{lcccc}
\hline \multicolumn{1}{c}{ Variable } & Coefficient & Std. Error & t-Statistic & Prob \\
\hline \multicolumn{1}{c}{ C } & 0.851353 & 0.241154 & 3.530327 & 0.0007 \\
$\mathrm{Z}$ & 0.253788 & 0.074443 & 3.409158 & 0.0011 \\
\hline R-squared & 0.145968 & Mean dependent var & 1.548 \\
Adjusted R-squared & 0.133409 & S.D. dependent var & 1.1509 \\
S.E. of regression & 1.071382 & Akaike info criterion & 3.003932 \\
Sum squared resid & 78.05448 & Schwarz criterion & 3.068174 \\
Log likelihood & -103.1376 & Hannan-Quinn criter. & 3.02945 \\
F-statistic & 11.62236 & & \\
Prob(F-statistic) & 0.0011 & Durbin-Watson stat & & 1.653549 \\
\hline
\end{tabular}

Sumber: olah data peneliti, 2021

Berdasarkan data pada tabel 5, menunjukan bahwa variabel penerapan green accounting mempunyai hasil probabilitas $0.0132<0.05$ yang artinya memiliki pengaruh 
dan signifikan terhadap nilai perusahaan yang diproyeksikan Tobins'Q dan memiliki arah hubungan positif dengan nilai koefisien regresi sebesar 2.273781 artinya nilai perusahaan akan meningkat sebesar 2.27 apabila perusahaan mampu mengungkapkan salah satu aspek atau kriteria penerapan green accounting dalam perusahaan. Hal ini sejalan dengan penelitian Abdurrahman (2019), Dewi \& Narayana (2020), Hassan (2018), dan Saputra \& Mahyuni (2018) yang menyatakan bahwa komitmen bisnis dalam mengimplementasikan alokasi biaya lingkungan akan meningkatkan nilai perusahaan dan membantu dalam mewujudkan pembangunan berkelanjutan sehingga kesan positif akan diterima oleh investor dan masyarakat, karena hal ini untuk menghindari sanksi negatif yang akan diterima oleh perusahaan diwaktu mendatang akibat masalah lingkungan, maka investor akan lebih percaya terhadap kestabilan perusahaan diwaktu yang akan datang.

Variabel penerapan green accounting mempunyai hasil probabilitas $0.0434<0.05$ yang artinya memiliki pengaruh dan signifikan terhadap nilai perusahaan yang diproyeksikan Tobins'Q dan memiliki arah hubungan positif dengan nilai koefisien regresi sebesar 2.041551 artinya nilai perusahaan akan meningkat sebesar 2.04 apabila perusahaan mampu mengungkapkan salah satu aspek atau kriteria Corporate Social Responsibility Disclosure dalam perusahaan. Chen \& Lee (2017), Putri \& Budiyanto (2018), dan Tunpornchai \& Hensawang (2018) menyatakan pelaksanaan Corporate Social Responsibility oleh perusahaan akan menjamin nilai perusahaan tumbuh secara berkelanjutan dengan tujuan untuk memperoleh kepercayaan oleh investor dan masyarakat.

Tabel 5 Analisis Regresi Berganda X Terhadap Y

\begin{tabular}{lcccc}
\hline \multicolumn{1}{c}{ Variable } & Coefficient & Std. Error & t-Statistic & Prob \\
\hline C & -0.53681 & 0.48443 & -1.108128 & 0.2718 \\
X1 & 2.273481 & 0.893425 & 2.545016 & 0.0132 \\
X2 & 2.041551 & 0.991741 & 2.058552 & 0.0434 \\
\hline R-squared & 0.247572 & Mean dependent var & 1.548 \\
Adjusted R-squared & 0.225112 & S.D. dependent var & 1.1509 \\
S.E. of regression & 1.013111 & Akaike info criterion & 2.90584 \\
Sum squared resid & 68.76835 & Schwarz criterion & 3.002204 \\
Log likelihood & -98.70439 & Hannan-Quinn criter. & & 2.944117 \\
F-statistic & 11.02256 & & & 0.571425 \\
Prob(F-statistic) & 0.000073 & Durbin-Watson stat & & \\
\hline
\end{tabular}

Sumber: olah data peneliti, 2021

Model analisis jalur digunakan untuk menunjukkan arah hubungan antar variabel penelitian yang dipengaruhi oleh adanya keberadaan variabel mediasi atau intervening dalam jalur pengaruh variabel, berikut adalah diagram arah jalur pengaruh variabel penelitian dan besarnya koefisien regresi yang dihasilkan pada persamaan sebelumnya. 
Gambar 2. Diagram Koefisien Analisis Jalur

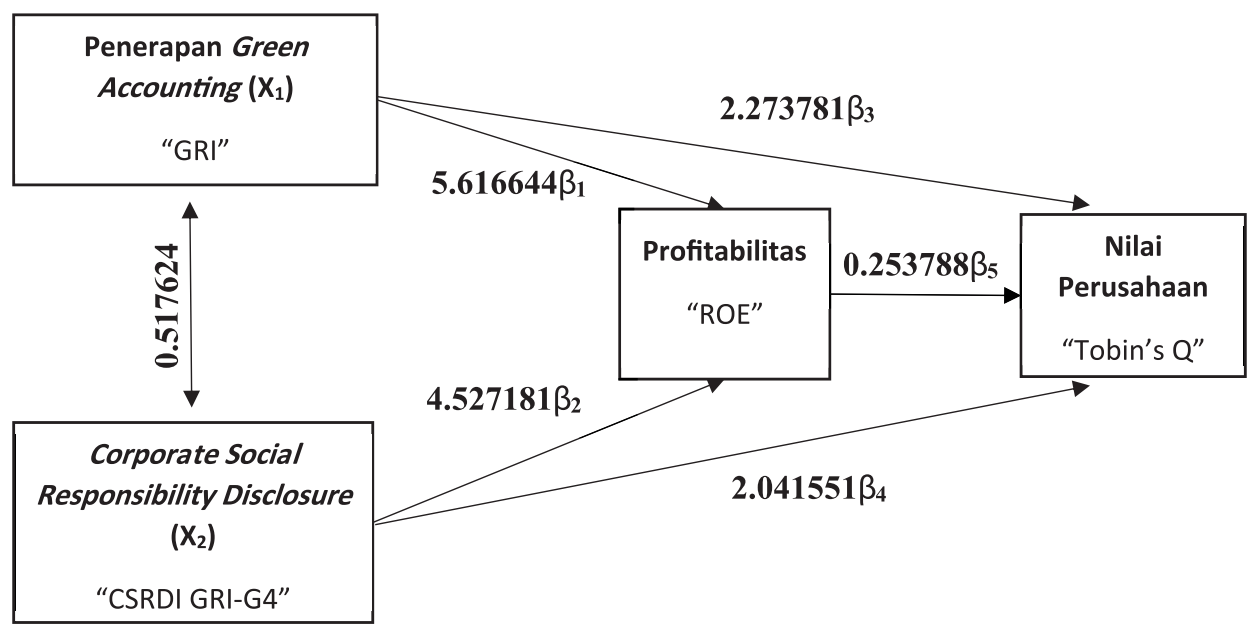

Hasil koefisien jalur tersebut dicari terlebih dahulu nilai koefisien jalur tidak langsungnya terlebih dahulu dengan mengalikan nilai estimasi variabel $\mathrm{X}$ ke $\mathrm{Y}$ dengan nilai estimasi variabel Y ke Z kemudian dibandingkan dengan Z Sobel Score yang diperoleh dengan rumus Sobel yang tertampil dibawah ini:

Tabel 5 Hasil Uji Signifikansi Sobel

\begin{tabular}{cccc}
\hline \multicolumn{2}{c}{ Pengaruh Tidak Langsung } & Z Sobel & \multicolumn{1}{c}{ Keterangan } \\
\hline GA $=>$ ROE $=>$ TOBINSQ & 1.425436 & 2.93881428 & $\begin{array}{c}\text { Z Sobel; > 1.96 Pengaruh Tak } \\
\text { Langsung Signifikan }\end{array}$ \\
CSRD $=>$ ROE $=>$ TOBINSQ & 1.148944 & 2.64946678 & $\begin{array}{c}\text { Z Sobel; > 1.96 Pengaruh Tak } \\
\text { Langsung Siginifikan }\end{array}$ \\
\hline
\end{tabular}

Sumber: olah data peneliti, 2021

Interpretasi hasil Z Sobel dihitung dengan mencari nilai test statistic sobel dengan menghitung rasio kritis antar koefisien korelasi hubungan tak langsung variabel $\mathrm{X}$ terhadap Y dengan standar error maka dapat ditemukan hasil Z Score nya. Pada pengaruh GA => ROE $=>$ TOBINSQ memperoleh nilai Z sobel $2.934>1.96$ maka dapat disimpulkan bahwa pengaruh tak langsung penerapan green accounting terhadap nilai perusahaan (Tobins'Q) signifikan melalui profitabilitas (ROE). Sementara itu, pada pengaruh CSRD $=>$ ROE => TOBINSQ memperoleh nilai Z sobel $2.649>1.96$ maka dapat disimpulkan bahwa pengaruh tak langsung Corporate Social Responsibility Disclosure terhadap nilai perusahaan (Tobins'Q) signifikan melalui profitabilitas (ROE).

\section{Variabel $\mathbf{X}_{1}$ Terhadap $\mathbf{Y}$}

Hasil pengujian Z Sobel Test variabel profitabilitas (ROE) menunjukkan nilai koefisien jalur regresi hubungan tak langsung X1 terhadap Y $1.425436<2.273781$ artinya lebih rendah dari hubungan langsung artinya kemampuan mediasi dari variabel profitabilitas 
pada pengaruh penerapan green accounting terhadap nilai perusahaan (Tobins'Q) belum dapat dibuktikan dalam penelitian ini. Hal ini perusahaan tidak berhasil menginternalisasi biaya lingkungan ke dalam laporan keuangan dengan harapan dapat mengefisiensi dan mengefektifkan biaya untuk mencegah adanya kerugian diwaktu yang akan datang, hal tersebut tidak cukup kuat untuk meningkatkan kepercayaan stakeholder karena biaya lingkungan tidak diklasifikasikan secara baik dalam struktur laporan posisi keuangan perusahaan, sehingga informasi mengenai biaya dan kerja lingkungan tersebar secara terpisah dalam laporan keberlanjutan (sustainability report), sehingga persepsi positif terhadap perusahaan sulit tercapai.

\section{Variabel $\mathbf{X}_{2}$ Terhadap $\mathbf{Y}$}

Hasil pengujian variabel profitabilitas (ROE) menunjukkan hasil nilai koefisien jalur regresi hubungan tak langsung X2 terhadap Y sebesar memperoleh nilai $1.148944<2.041551$ artinya lebih rendah dari hubungan langsung artinya kemampuan mediasi dari variabel profitabilitas pada pengaruh Corporate Social Responsibility Disclosure terhadap nilai perusahaan (Tobins'Q) belum dapat dibuktikan dalam penelitian ini. Hal ini dikarenakan informasi yang tersebar tidak merata mengenai kegiatan CSR yang diungkapkan perusahaan dalam laporan tersendiri yaitu laporan keberlanjutan (sustainability report) dan sering dibagikan informasi kegiatan tersebut dalam halam tersendiri dalam website yang memudahkan perusahaan untuk membangun sentiment positif terhadap stakeholder. CSRD sendiri berisi mengenai berbagai macam hal Ekonomi, Sosial, Lingkungan, Masyarakat dan Tanggungjawab Produk informasi yang lengkap dan sistematis tersebut tidak cukup untuk membantu perusahaan memperoleh posisi dalam persaingan pasar dan meningkatkan keunggulan dan daya saing usaha, hal inilah yang kemudian dapat menghambat penjualan perusahaan dan secara tak langsung tidak akan meningkatkan ketertarikan terhadap penanaman modal dalam instrumen saham perusahaan.

Penerapan green accounting berpotensi untuk meningkatkan profitabilitas perusahaan, hal ini berdasarkan hasil perolehan dan analisis data yang menunjukkan bahwa berpengaruh dan signifikan artinya apabila perusahaan dapat menerapkan dan meningkatkan pengungkapan atas kinerja lingkungannya maka akan termasuk sebagai salah satu upaya penerapan dalam green accounting yang secara tak langsung akan meningkatkan profitabilitas karena dapat memberikan citra positif produk atau jasa baik bagi lingkungan dan sosial, sebaliknya apabila tidak diterapkan akan menurunkan daya jual produk sehingga profit akan menurun.

Corporate Social Responsibility Disclosure berpotensi untuk meningkatkan profitabilitas perusahaan, hal ini berdasarkan hasil perolehan dan analisis data yang menunjukkan bahwa berpengaruh dan signifikan artinya apabila perusahaan dapat menerapkan dan meningkatkan pengungkapan atas informasi kegiatan CSR akan meningkatkan profitabilitas karena dapat memberikan citra dan sentiment positif kepada masyarakat disekitar sehingga rasa percaya terhadap produk atau jasa perusahaan akan sampai kepada masyarakat, sebaliknya apabila tidak diterapkan akan menurunkan daya jual produk sehingga profit akan menurun. 
Profitabilitas berpotensi untuk meningkatkan nilai perusahaan, hal ini berdasarkan hasil perolehan dan analisis data yang menunjukkan bahwa berpengaruh dan signifikan artinya apabila perusahaan dapat meningkatkan profitabilitasnya akan meningkatkan nilai perusahaan dipasar bursa, karena para investor sangat yakin dan percaya terhadap modal yang akan disetor kepada perusahaan akan membawa tingkat pengembalian dan dividen yang tinggi, sebaliknya apabila profit rendah maka minat investor akan menurun, sehingga nilai perusahaan akan ikut menurut.

\section{SIMPULAN}

Penerapan green accounting berpengaruh dan signifikan terhadap nilai perusahaan artinya apabila perusahaan dapat menerapkan dan meningkatkan pengungkapan atas kinerja lingkungannya maka akan termasuk sebagai salah satu upaya penerapan dalam green accounting yang secara tak langsung akan meningkatkan nilai perusahaan karena dapat memberikan citra positif dan rasa percaya terhadap stakeholder atas keberlangsungan perusahaan dimasa depan. Corporate Social Responsibility Disclosure berpengaruh dan signifikan terhadap nilai perusahaan artinya apabila perusahaan dapat menerapkan dan meningkatkan pengungkapan atas informasi CSR akan meningkatkan nilai perusahaan karena dapat memberikan citra positif dan rasa percaya terhadap stakeholder atas kontribusi perusahaan terhadap lingkungan dan sosial disekitarnya. Profitabilitas belum mampu menjadi mediasi antara pengaruh penerapan green accounting terhadap nilai perusahaan artinya penerapan green accounting belum dilaksanakan secara maksimal untuk memberikan rasa percaya terhadap produk dalam rangka menyokong nilai perusahaan, sehingga tidak termasuk ke dalam faktor kuat untuk memediasi hubungan antara green accounting terhadap nilai perusahaan. Profitabilitas belum mampu menjadi mediasi antara pengaruh Corporate Social Responsibility Disclosure terhadap nilai perusahaan artinya Corporate Social Responsibility Disclosure belum dilaksanakan secara maksimal untuk memberikan rasa percaya terhadap produk dalam rangka menyokong nilai perusahaan, sehingga tidak termasuk ke dalam faktor kuat untuk memediasi hubungan antara Corporate Social Responsibility Disclosure terhadap nilai perusahaan.

Berdasarkan hasil penelitian yang telah dilakukan, maka peneliti dapat memberikan implikasi terhadap berbagai pihak baik secara teoritis maupun praktis. Pertama, untuk investor, penerapan green accounting dan Corporate Social Responsibility Disclosure dapat dijadikan sebagai sumber penilaian terhadap kinerja perusahaan dalam memenuhi tanggungjawabnya terhadap kepedulian lingkungan-sosial dan taat dengan hukum yang berlaku sebagai akibat dari aktivitas perusahaan yang berpotensi mencemari dan merusak lingkungan sekitarnya, sehingga investor dapat lebih mendukung dan mendorong perusahaan untuk lebih peduli terhadap lingkungan-sosial sekitarnya. Kedua, untuk pemerintah, dalam penelitian ini ditemukan banyak perusahaan manufaktur yang sudah terdaftar dalam pasar bursa namun belum mengikuti kegiatan PROPER. Program PROPER ini bertujuan memberik penilaian yang lebih komprehensif dan mendalam mengenai gerakan perusahaan dalam membangun program-program peduli lingkungan dan terbukti taat terhadap aturan dan hukum yang berlaku. Ketiga, untuk pihak perusahaan diharapkan mulai mengikuti standar 
akuntansi lingkungan yang telah disusun oleh Ikatan Akuntan Indonesia dalam PSAK untuk mencamtukan lingkungan sebagai bagian dari aset dalam perusahaan dan biayabiaya yang dipergunakna untuk perbaikan, pencengahan dan pengambangan lingkungan dapat dicatat dalam posisi kewajiban perusahaan dan dilaporkan dalam laporan keungan sehingga memberikan informasi yang dapat melengkapi badan posisi laporan keungan perusahaan secara utuh dan menyeluruh.

\section{PUSTAKA ACUAN}

Abdurrahman, A. P. (2019). Impact of Green Accounting on Company Value : Evidence from the Nigerian Companies. Journal of Business Management and Accounting, 3(1), 16-26.

Ali, H. Y., Danish, R. Q., \& Asrar-ul-Haq, M. (2019). How corporate social responsibility boosts firm financial performance: The mediating role of corporate image and customer satisfaction. WILEY: Corporate Social Responsibility and Environmental Management, 27(1), 166-177. https://doi.org/10.1002/csr.1781

Andries, P., \& Stephan, U. (2019). Environmental innovation and firm performance: How firm size and motives matter. Sustainability (Switzerland), 11(13), 1-17. https://doi. org/10.3390/su11133585

Angelia, D., \& Suryaningsih, R. (2015). The Effect of Environmental Performance And Corporate Social Responsibility Disclosure Towards Financial Performance ( Case Study to Manufacture, Infrastructure, And Service Companies That Listed At Indonesia Stock Exchange ). Procedia Social and Behavioral Sciences, 211(September), 348-355. https:// doi.org/10.1016/j.sbspro.2015.11.045

Ayem, S., \& Nugroho, R. (2016). Pengaruh Profitabilitas, Struktur Modal, Kebijakan Dividen, dan Keputusan Investasi Terhadap Nilai Perusahaan. Jurnal Akuntansi, 4(1), 31-39.

Ayu, D. P., \& Suarjaya, G. A. A. (2017). Pengaruh Profitabilitas Pada Nilai Perusahaan dengan Corporate Social Responsibility Sebagai Variabel Moderasi. E-Jurnal Akuntansi, 22(2), 1600-1625. https://doi.org/10.24843/EJA.2018.v22.i02.p29

Brigham, E. F., \& Houston, J. F. (2007). Dasar-Dasar Manajemen Keuangan : Fundamentals of Financial Management (A. Akbar (ed.); 11th ed.). Salemba Empat.

Cahyanti, N. W. N., Nuzula, N. F., \& Nurlaily, F. (2018). Pengaruh Corporate Social Responsibility Disclosure (CSRD) Terhadap Profitabilitas Perusahaan ( Studi Pada Perusahaan Manufaktur yang Terdaftar di BEI Periode 2016 ). Jurnal Administrasi Bisnis, 61(2), 69-78.

Chen, R. C. Y., \& Lee, C. (2017). The influence of CSR on firm value: an application of panel smooth transition regression on Taiwan. Applied Economics, 49(34), 3422-3434. https://doi.org/10.1080/00036846.2016.1262516

Dewi, P. P., \& Narayana, I. P. E. (2020). Implementasi Green Accounting, Profitabilitas dan Corporate Social Responsibility pada Nilai Perusahaan. E-Jurnal Akuntansi, 30(12), 3252-3262. https://doi.org/doi.org/10.24843/EJA.2020.v30.i12.p20

Dianawati, C. P., \& Fuadati, S. R. (2016). Pengaruh CSR Dan GCG Terhadap Nilai Perusahaan: Profitabilitas Sebagai Variabel Intervening. Jurnal Ilmu Dan Riset Manajemen, 5(1), 1-20. 
Endiana, I. D. M., Luh, N., \& Mahayu, G. (2020). The Effect of Green Accounting on Corporate Sustainability and Financial Performance. Journal of Asian Finance, Economics and Business, 7(12), 731-738. https://doi.org/10.13106/jafeb.2020.vol7.no12.731

Ezeagba, C. E., Rachael, J.-A. C., \& Chiamaka, U. (2017). Environmental Accounting Disclosures and Financial Performance: A Study of selected Food and Beverage Companies in Nigeria (2006-2015). International Journal of Academic Research in Business and Social Sciences, 7(9), 162-174. https://econpapers.repec.org/ RePEc:hur:ijarbs:v:7:y:2017:i:9:p:162-174

Hamdani. (2016). Good Corporate Governance (Tinjauan Etik Dalam Bisnis) (Pertama). Mitra Wacana Media.

Harmono. (2014). Manajemen Keuangan Berbasis Balanced Scorecard (Pendekatan Teori, Kasus, dan Riset Bisnis) (Ketiga). Bumi Aksara.

Hassan, O. A. G. (2018). The impact of voluntary environmental disclosure on firm value: Does organizational visibility play a mediation role? Business Strategy and the Environment, 27(8), 1569-1582. https://doi.org/10.1002/bse.2217

Ikhsan, A. (2008). Akuntansi Lingkungan dan Pengungkapannya (Duabelas). Graha Ilmu. Kasmir. (2018). Analisa Laporan Keuangan (kesebelas). Raja Grafindo Persada.

Khairiyani, K., Mubyarto, N., Mutia, A., Zahara, A. E., \& Habibah, G. W. I. A. (2019). Kinerja Lingkungan Terhadap Kinerja Keuangan Serta Implikasinya Terhadap Nilai Perusahaan. ILTIZAM Journal of Shariah Economic Research, 3(1), 41. https://doi.org/10.30631/ iltizam.v3i1.248

Kusumaningtias, R. (2013). Green Accounting, Mengapa dan Bagaimana? PROCEEDING SEMINAR NASIONAL DAN CALL FOR PAPERS SANCALL 2013, 978-979.

Mardikanto, T. (2014). (CSR Corporate Social Responsibility) Tanggungjawab Sosial Korporasi. Alfabeta.

Masitoh, D., \& Suprijanto, P. D. P. dan A. (2018). Pengaruh Corporate Social Responsibility, Debt To Equity Ratio Terhadap Nilai Perusahaan Dengan Profitabilitas Sebagai Variabel Intervening (Studi Empiris pada Perusahaan Manufaktur Sektor Pertambangan di Bursa Efek Indonesia Periode Tahun 2011-2017). Journal Of Accounting, 4(4), 1-13.

Mowen, M. M., Hansen, D. R., \& Heitger, D. L. (2016). Managerial Accounting: The Cornerstone of Business Decision Making (6th ed.). Cengage Learning.

Munawir. (2014). Analisa Laporan Keuangan (Kelima). Liberty.

Nor, H. (2011). Corporate Social Responsibility. Graha Ilmu.

Nurkhin, A. (2009). Corporate governance dan profitabilitas; Pengaruhnya terhadap pengungkapan tanggung jawab sosial perusahaan (Studi empiris pada perusahaan yang terdaftar di bursa efek indonesia). Jurnal Akuntansi Diponegoro, 1-97.

Omran, M. A., \& Ramdhony, D. (2015). Theoretical Perspectives on Corporate Social Responsibility Disclosure: A Critical Review. International Journal of Accounting and Financial Reporting, 5(2), 38. https://doi.org/10.5296/ijafr.v5i2.8035 
Pratiwi, N., \& Rahayu, Y. (2018). Pengaruh Penerapan Green Accounting Terhadap Pertumbuhan Harga Saham dengan Profitabilitas Sebagai Variabel Moderating. Jurnal Ilmu Dan Riset Akuntansi, 7(8), 1-15.

Putri, Z. B., \& Budiyanto. (2018). Pengaruh Corporate Social Responsibility Terhadap Nilai Perusahaan Dengan Kepemilikan Manajerial Sebagai Variabel Moderating. Jurnal Ilmu Dan Riset Manajemen, 7(3), 361-375.

Rahayu, M. B. (2020). Pengaruh Profitabilitas Terhadap Struktur Keuangan. Jurnal Studi Manajemen Dan Bisnis, 5(2), 75-79. https://doi.org/10.21107/jsmb.v5i2.6656

Risal, T., Lubis, N., \& Argatha, V. (2020). Implementasi Green Accounting Terhadap Profitabilitas Perusahaan. Accumulated Journal, 2(1), 73-85.

Riyadh, H. A., Al-shmam, M. A., Huang, H. H., \& Gunawan, B. (2020). The Analysis of Green Accounting Cost Impact on Corporations Financial Performance. International Journal of Energy Economics and Policy, 10(6), 421-426. https://doi.org/10.32479/ijeep.9238

Rosdwianti, M. K., \& Dzulkirom AR, M. (2016). Pengaruh Corporate Social Responsibility (CSR) Terhadap Profitabilitas Perusahaan. Jurnal Administrasi Bisnis S1 Universitas Brawijaya, 38(2), 16-22.

Saputra, I. P. A., \& Mahyuni, L. P. (2018). Pengaruh Struktur Kepemilikan dan Kinerja Lingkungan Terhadap Nilai Perusahaan. Jurnal Manajemen Dan Bisnis, 15(3), 64-81.

Sari, I. A. G. D. M. (2020). Profitability and liquidity on firm value and capital structure as intervening variable. International Research Journal of Management, IT and Social Sciences, 7(1), 116-127. https://doi.org/10.21744/irjmis.v7n1.828

Soliha, E., \& Taswan. (2002). Pengaruh Kebijakan Hutang Terhadap Nilai Perusahaan Serta Beberapa Faktor Yang Mempengaruhinya. Jurnal Bisnis Dan Ekonomi, 2(9), 149-163.

Suhartini, D., \& Megasyara, I. (2019). Pengaruh Corporate Social Responsibility Disclosure Terhadap Nilai Perusahaan Dengan Profitabilitas Sebagai Variabel Intervening Pada Perusahaan Sektor Pertambangan Yang Terdaftar Di Bursa Efek Indonesia Tahun 2012-2016. EQUITY: Jurnal EKonomi, Manajemen, Akuntansi, 21(2), 129. https:// doi.org/10.34209/equ.v21i2.639

Tunpornchai, W., \& Hensawang, S. (2018). Effects of Corporate Social Responsibility and Corporate Governance on Firm Value : Empirical Evidences of the Listed Companies on the Stock Exchange of Thailand in the SET100. International Journal of Interdisciplinary Research, 7(1), 161-170.

Wangi, W. R., \& Lestari, R. (2020). Pengaruh Penerapan Green Accounting terhadap Tingkat Profitabilitas Perusahaan. Prosiding Akuntansi, 6(1), 489-493.

Wulandari, S. (2020). Pengaruh Corporate Social Responsibility (CSR) Disclosure terhadap Profitabilitas Perusahaan (Studi Empiris Pada Perusahaan Subsektorperkebunan Di Bursa Efekindonesia). Journal of Economic and Management, 19(37), 1-14.

Yulianty, R., \& Nugrahanti, T. P. (2020). Pengaruh Sustainability Reporting Terhadap Nilai Perusahaan denga Kinerja Keuangan Sebagai Variabel Intervening. Jurnal Riset Perbankan Manajemen Dan Akuntansi, 4(1), 12-23. 
Zuhroh, I. (2019). The Effects of Liquidity, Firm Size, and Profitability on the Firm Value with Mediating Leverage. KnE Social Sciences, 3(13), 203. https://doi.org/10.18502/ kss.v3i13.4206

Zulhaimi, H. (2015). Pengaruh Penerapan Green Accounting Terhadap Kinerja Perusahaan. Jurnal Riset Akuntansi Dan Keuangan, 3(1), 603. https://doi.org/10.17509/jrak.v3i1.6607 